\title{
Early cannabis use and its relation to the development of psychiatric disorders: a review
}

\author{
Carlos Roncero, ${ }^{1}$ Raúl Felipe Palma-Álvarez, ${ }^{2,3,4}$ Víctor Barrau, ${ }^{2,4,5}$ Neide Urbano, ${ }^{6}$ Nieves Martínez-Luna, ${ }^{2,3,4}$ \\ María Bettina Ortiz-Medina, ${ }^{7}$ Constanza Daigre ${ }^{4,5}$
}

\begin{abstract}
1 Servicio de Psiquiatría, Complejo Asistencial Universitario de Salamanca (CAUSA), Instituto de Biomedicina de Salamanca (IBSAL), Universidad de Salamanca, Salamanca, España.

2 Servicio de Psiquiatría, Hospital Universitario Vall d'Hebrón, CIBERSAM. Barcelona, España.

3 Departamento de Psiquiatría, Universidad Autónoma de BarceIona, Barcelona, España.

${ }^{4}$ Sección de Adiciones y Patología Dual. Hospital Universitario Vall d'Hebrón-ASPB, Barcelona, España.

5 Institut de Recerca Hospital Vall d'Hebrón, Barcelona, España.

6 Área de Psiquiatria da Infância e da Adolescência, Centro Hospitalar de Lisboa Central, EPE, Hospital Dona Estefânia, Lisboa, Portugal.

7 Área de Psicogeriatría, Hospital Mare de Deu de la Mercè, BarceIona, España.
\end{abstract}

\section{Correspondence:}

Carlos Roncero

Servicio de Psiquiatría, Complejo Asistencial Universitario de Salamanca, Instituto de Biomedicina de Salamanca, Universidad de Salamanca.

Paseo de San Vicente 58-182, 37067, Salamanca, España.

Phone: +34 923 29-1200 ext. 55448 Email: croncero@saludcastillayleon.

Received first version: May 4, 2017 Second version: October 10, 2017 Accepted: November 10, 2017

doi:10.17711/SM.0185-3325.2017.037

\begin{abstract}
Background. Cannabis is the most widely used illegal drug in the world. Both an early cannabis use onset and the amount used contribute to the risk of suffering mental disorders in adulthood. Objective. Review longitudinal studies conducted on adolescents associating early cannabis use with the subsequent occurrence of mental disorders. Method. A search was conducted in PubMed until December 2016, focusing on longitudinal researches and prioritizing studies that clearly distinguished between an early and late onset of cannabis use. To achieve the objective, the word "cannabis" was used in combination with the main psychiatric diseases. A manual search of articles that appeared in the references was also conducted. Results. Fifteen studies met the inclusion criteria, but only five studies discriminated clearly between early and late onset of cannabis use. An association was found between early onset of cannabis use and mental disorders, particularly psychosis. The information regarding affective and anxiety disorders is more controversial. Discussion and conclusion. Early onset of cannabis use is associated with mental disorders, especially psychosis. Prevention plans for cannabis use in adolescents should be developed in order to decrease the risk of mental disorders.
\end{abstract}

Keywords: Adolescence, cannabis, early drug use, psychosis, psychiatric disorders.

\section{RESUMEN}

Antecedentes. El cannabis es la droga ilegal más consumida en todo el mundo. Tanto el inicio de su consumo a una edad temprana como la cantidad consumida aumentan el riesgo de padecer enfermedades mentales en la vida adulta. Objetivo. Revisión narrativa de artículos longitudinales realizados en adolescentes donde se relacionaron el uso temprano de cannabis con la posterior aparición de alteraciones psicopatológicas. Método. Se realizó una búsqueda en la base de datos de PubMed hasta diciembre de 2016. Se priorizaron los estudios longitudinales en adolescentes que establecieron diferencias entre inicio temprano versus tardío de uso de cannabis. Para ello se utilizó la palabra cannabis en combinación con las principales enfermedades psiquiátricas. Además, se llevó a cabo una búsqueda manual de artículos que aparecían en las referencias. Resultados. Se encontraron 15 estudios longitudinales en adolescentes que relacionaban el uso de cannabis con alteraciones mentales; sólo cinco de ellos hacían una diferenciación clara entre inicio temprano versus tardío. Se encontró que hay una asociación entre el consumo de cannabis en edades tempranas con la presencia de alteraciones psicopatológicas, especialmente de trastornos psicóticos. En cuanto a los trastornos afectivos y el consumo temprano de cannabis, la asociación es algo más controvertida. Discusión y conclusión. El uso de cannabis en edades tempranas podría llevar a presentar posteriormente trastornos mentales, sobre todo psicosis. Identificar el consumo de drogas en adolescentes y adultos jóvenes es una estrategia que puede influir en el establecimiento de planes de prevención para evitar y/o disminuir el riesgo de desarrollo de patología mental.

Palabras clave: Adolescencia, cannabis, consumo precoz de cannabis, psicosis, trastornos psiquiátricos. 


\section{BACKGROUND}

Cannabis is the illegal drug with the highest prevalence of use worldwide, with usage rates of $3.9 \%$ across all cultures, and representing 180.6 million users, 13.1 million of which meet dependency criteria (Degenhardt et al., 2013). The past two decades saw an increase in cannabis use that appears to have stabilized in many European countries, although there are still high levels of use, especially among the adolescent population, coupled with a lifetime prevalence of use of 23.8.\% among adult Europeans (80.5 million) (European Monitoring Center for Drugs and Drug Addiction, 2010).

The problem of cannabis use in adolescents has been documented in Europe (European Monitoring Center for Drugs and Drug Addiction, 2010), North America (Currie et al., 2012), and Latin America, where marijuana is said to be the most commonly used illegal drug among high school students (Inter-American Commission for the Control of Drug Abuse, 2006). Most countries in the Americas have witnessed an increase in cannabis seizures in recent years, particularly those in South America (United Nations Office on Drugs and Crime, 2008).

Studying the child-youth population is important because early onset of use (before age 15), associated with chronic use in young people increases cognitive impairment in executive and neurocognitive functions (Curran et al., 2016; Fontes et al., 2011), and may be associated with the development of dependency in adulthood (Gonzalvo, Barral, Grau-López, Esteve, \& Roncero, 2011). This high use may be partly due to the fact that people tend to consider this drug as one of the least harmful in the short and long term, compared with other substances. In addition, cannabis use at early ages could have consequences at the cerebral level since neurodevelopment continues to occur at this stage (Parolaro, 2010).

Due to the serious consequences mentioned earlier with respect to early cannabis use, a review of articles associating psychopathology with early vs. late cannabis use is proposed. It is also suggested that early cannabis use leads to greater exposure of the Central Nervous System to this substance and, therefore, a greater risk of the presence of psychopathological alterations. The purpose of this review is to describe the relationship between early cannabis use and the development of mental disorders.

\section{METHOD}

A narrative review was conducted of longitudinal studies on humans, which associated early cannabis use with mental disorders (psychosis, schizophrenia, bipolar disorder, depression, and anxiety). Given that the concept of early onset of cannabis use varies, studies were included that focused on cannabis use during adolescence and more emphasis was placed on studies that clearly distinguish between early vs. late cannabis use. On the other hand, only longitudinal studies that provide data on incidents and cause-effect correlations with greater scientific evidence than other types of studies were chosen (Bel, Inglés, \& Piñol, 2009). A search of the PubMed database was conducted until December 31, 2016. Cannabis combinations have been used with other keywords: age of onset, mental disorders, psychosis, schizophrenia, depression, anxiety, and bipolar disorder. In addition, bibliographic citations from reviews and meta-analyses in this topic were manually reviewed in order to find additional studies with the characteristics we were looking for (longitudinal studies).

\section{RESULTS}

A total of 1038 articles were found, and after reviewing the titles and abstracts, 37 articles were selected for reading (Figure 1). It should be noted that seven systematic reviews and/or meta-analyses were located relating cannabis use and mental disorders (without specifying whether early cannabis use was involved). Of these publications, the studies included were reviewed to determine whether any of them met the criteria for this paper.

Thus, 15 articles were found that met the inclusion criteria. These were longitudinal articles relating cannabis use in youth to mental disorders, although only five publications made a clear distinction (including specific ages) between early vs. late onset of cannabis use and mental disorders. It should be noted that each of these five studies arbitrarily used a different age criterion to define what was an early or late onset of cannabis use; in other words, age of early onset could vary between 15 and 18 years according to the study in question. The remaining studies analyzed adolescent cohorts, in which they related the onset of cannabis use with the onset of later mental disorders (Table 1). Accordingly,

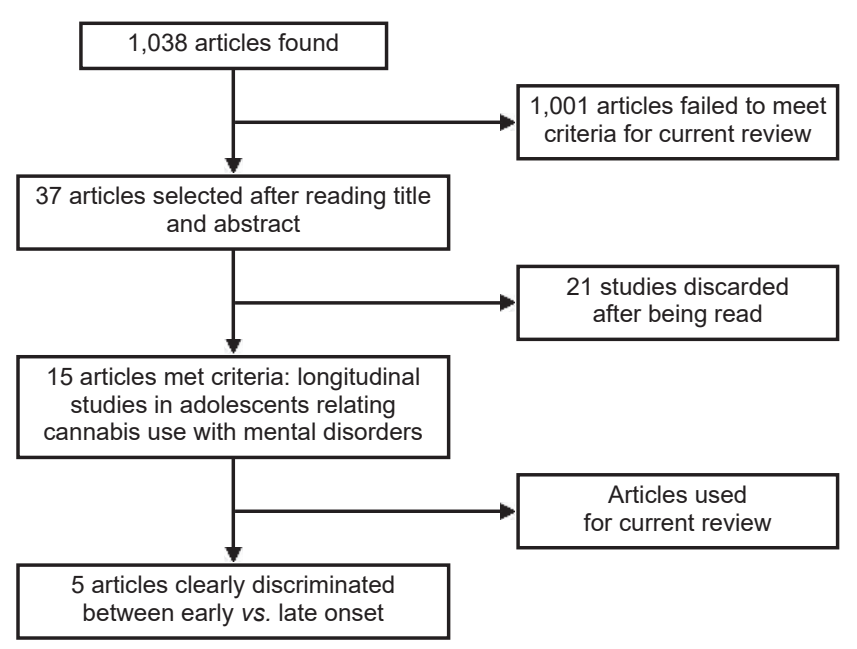

Figure 1. Flow chart of selected articles. 
Table 1

Longitudinal studies relating cannabis use in adolescence to mental disorders (psychosis, mood disorders and anxiety); studies that clearly discriminated between early and late onset of cannabis use are indicated

\begin{tabular}{|c|c|c|c|c|c|c|}
\hline \multirow[b]{2}{*}{$\begin{array}{l}\text { Author } \\
\text { and year }\end{array}$} & \multirow[b]{2}{*}{ Sample } & \multirow[b]{2}{*}{$\begin{array}{l}\text { Monitoring } \\
\text { time (years) }\end{array}$} & \multirow[b]{2}{*}{ Correlation } & \multicolumn{2}{|c|}{$\begin{array}{l}\text { Definition of early age } \\
\text { of onset of cannabis use }\end{array}$} & \multirow[b]{2}{*}{ Conclusions } \\
\hline & & & & $\begin{array}{l}\text { Specifica- } \\
\text { tions }\end{array}$ & Comment & \\
\hline $\begin{array}{l}\text { Andréasson } \\
\text { et al., } 1987\end{array}$ & 45570 & 15 & $\begin{array}{c}\text { Psychosis } \\
\text { (schizophrenia) }\end{array}$ & No & $\begin{array}{l}\text { The sample included } \\
\text { young people over } 18 \text { en- } \\
\text { tering military service. }\end{array}$ & $\begin{array}{l}\text { There is an up to six times greater relative risk of de- } \\
\text { veloping schizophrenia in frequent cannabis users } \\
\text { (using cannabis more than } 50 \text { times during lifetime) } \\
\text { compared to people who never use cannabis. }\end{array}$ \\
\hline $\begin{array}{l}\text { Arseneault } \\
\text { et al., } 2002\end{array}$ & 759 & 26 & $\begin{array}{l}\text { Psychosis } \\
\text { (schizophrenia), } \\
\text { depression }\end{array}$ & Yes & $\begin{array}{l}\text { Cannabis use was con- } \\
\text { sidered early if the first } \\
\text { use took place under the } \\
\text { age of } 15\end{array}$ & $\begin{array}{l}\text { The use of cannabis in adolescence increases the } \\
\text { risk of presenting schizophrenia in adulthood, the } \\
\text { risk being higher if cannabis is used before the age } \\
\text { of } 15 \text {. Early cannabis use is not related to depres- } \\
\text { sion in adulthood. }\end{array}$ \\
\hline $\begin{array}{l}\text { Caspi et al., } \\
2005\end{array}$ & 1037 & 26 & $\begin{array}{l}\text { Psychosis } \\
\text { and } \\
\text { polymorphism } \\
\text { in the COMT }\end{array}$ & Yes & $\begin{array}{l}\text { Cannabis use was con- } \\
\text { sidered early if the first } \\
\text { use took place under the } \\
\text { age of } 18\end{array}$ & $\begin{array}{l}\text { A functional polymorphism of COMT interacts with } \\
\text { young cannabis users and predicts psychosis in } \\
\text { adulthood, but this is not evident in those who begin } \\
\text { using cannabis in adulthood. }\end{array}$ \\
\hline $\begin{array}{l}\text { Ferdinand } \\
\text { et al., } 2005\end{array}$ & 1580 & 14 & Psychosis & No & $\begin{array}{l}\text { The basal age at the time } \\
\text { of recruitment was be- } \\
\text { tween } 4 \text { and } 16 \text { years. }\end{array}$ & $\begin{array}{l}\text { Cannabis use predicts the future presence of psy- } \\
\text { chotic symptoms (the average interval between the } \\
\text { use of cannabis and the appearance of psychotic } \\
\text { symptoms was } 4.6 \text { years). }\end{array}$ \\
\hline $\begin{array}{l}\text { Fergusson } \\
\text { et al., } 2002\end{array}$ & 1265 & 21 & $\begin{array}{l}\text { Depression } \\
\text { (and suicidal } \\
\text { behavior) }\end{array}$ & Yes & $\begin{array}{l}\text { It divided the sample into } \\
\text { three groups by age of on- } \\
\text { set of cannabis use (14- } \\
15,17-19,20-21 \text { years). }\end{array}$ & $\begin{array}{l}\text { The age of onset of cannabis use is not related to de- } \\
\text { pression, but is related to suicidal ideation (at a young- } \\
\text { er age of onset of cannabis use [14-15 years] and a } \\
\text { greater possibility of presenting suicidal ideation). }\end{array}$ \\
\hline $\begin{array}{l}\text { Fergusson } \\
\text { et al., } 2003\end{array}$ & 1265 & 21 & Psychosis & Partially & $\begin{array}{l}\text { They divided the sample } \\
\text { into the presence of psy- } \\
\text { chotic symptoms at the } \\
\text { ages of } 18 \text { and } 21\end{array}$ & $\begin{array}{l}\text { Cannabis dependence is associated with the devel- } \\
\text { opment of psychotic symptoms. }\end{array}$ \\
\hline $\begin{array}{l}\text { Fergusson } \\
\text { et al., } 2006\end{array}$ & 1265 & 25 & Psychosis & Partially & $\begin{array}{l}\text { They divided the sample } \\
\text { by cohort }(18,21 \text { and } 25 \\
\text { years). }\end{array}$ & $\begin{array}{l}\text { Regular cannabis use increases the risk of present- } \\
\text { ing with psychosis, all ages were statistically signifi- } \\
\text { cant in relation to cannabis use and the presence of } \\
\text { psychotic symptoms. }\end{array}$ \\
\hline $\begin{array}{l}\text { Hayatbakhsh } \\
\text { et al., } 2007\end{array}$ & 3239 & 21 & $\begin{array}{l}\text { Depression, } \\
\text { anxiety }\end{array}$ & Yes & $\begin{array}{l}\text { Cannabis use considered } \\
\text { early if first use took place } \\
\text { under the age of } 15\end{array}$ & $\begin{array}{l}\text { There is a relationship between early onset of can- } \\
\text { nabis use and anxious-depressive symptoms, re- } \\
\text { gardless of family or personal history. }\end{array}$ \\
\hline $\begin{array}{l}\text { Henquet } \\
\text { et al., } 2005\end{array}$ & 2437 & 4 & Psychosis & No & $\begin{array}{l}\text { The age of recruitment was } \\
\text { between } 14 \text { and } 24 \text { years. }\end{array}$ & $\begin{array}{l}\text { Moderate cannabis use among the young popula- } \\
\text { tion increases the risk of psychotic symptoms. }\end{array}$ \\
\hline $\begin{array}{l}\text { Kuepper } \\
\text { et al., } 2011\end{array}$ & 1923 & 10 & Psychosis & No & $\begin{array}{l}\text { The age of recruitment } \\
\text { was between } 14 \text { and } 24 \\
\text { years. }\end{array}$ & $\begin{array}{l}\text { Cannabis use is a risk factor for the development } \\
\text { of psychotic symptoms and disorders. This associa- } \\
\text { tion seems to be independent of age, sex, socioeco- } \\
\text { nomic status, use of other drugs, place of residence } \\
\text { (rural vs. urban), and childhood trauma. }\end{array}$ \\
\hline $\begin{array}{l}\text { Manrique- } \\
\text { García et al., } \\
2012\end{array}$ & 50087 & 35 & $\begin{array}{c}\text { Psychosis } \\
\text { (schizophrenia) }\end{array}$ & No & $\begin{array}{l}\text { The sample included } \\
\text { young people over } 18 \\
\text { entering military service } \\
\text { ( } 93 \% \text { of the sample was } \\
\text { aged between } 18 \text { and } 19 \\
\text { at baseline). }\end{array}$ & $\begin{array}{l}\text { Cannabis use increases the risk of presenting } \\
\text { schizophrenia up to three times. }\end{array}$ \\
\hline $\begin{array}{l}\text { Marmorstein } \\
\text { \& lacono, } \\
2011\end{array}$ & 1252 & 8 & Depression & No & $\begin{array}{l}\text { The basal age at the time } \\
\text { of recruitment was } 17\end{array}$ & $\begin{array}{l}\text { The psychosocial consequences associated with } \\
\text { cannabis use in adolescence explain its relationship } \\
\text { with the subsequent presence of major depressive } \\
\text { disorder. }\end{array}$ \\
\hline $\begin{array}{l}\text { Patton et al., } \\
2002\end{array}$ & 1601 & 7 & $\begin{array}{l}\text { Depression, } \\
\text { anxiety }\end{array}$ & No & $\begin{array}{l}\text { The age of recruitment } \\
\text { was between } 14 \text { and } 15 \\
\text { years. }\end{array}$ & $\begin{array}{l}\text { Frequent cannabis use in adolescent women is as- } \\
\text { sociated with subsequent depression and anxiety, } \\
\text { with adolescents who use cannabis on a daily basis } \\
\text { being at the greatest risk. }\end{array}$ \\
\hline $\begin{array}{l}\text { Zammit } \\
\text { et al., } 2002\end{array}$ & 50087 & 26 & $\begin{array}{c}\text { Psychosis } \\
\text { (schizophrenia) }\end{array}$ & No & $\begin{array}{l}\text { The age of recruitment } \\
\text { was between } 18 \text { and } 20 \\
\text { years in } 98 \% \text { of the sam- } \\
\text { ple. }\end{array}$ & $\begin{array}{l}\text { Self-reported cannabis use in early adulthood } \\
\text { (18-20 years) is a risk factor for the development } \\
\text { of schizophrenia. Risk increases directly with fre- } \\
\text { quency of use and amount used (the greatest risk } \\
\text { occurs in users who report usage on more than } 50 \\
\text { occasions). }\end{array}$ \\
\hline $\begin{array}{l}\text { Zammit } \\
\text { et al., } 2011\end{array}$ & 2630 & 2 & Psychosis & Yes & $\begin{array}{l}\text { Cannabis use considered } \\
\text { early if first use took place } \\
\text { under the age of } 14\end{array}$ & $\begin{array}{l}\text { The greatest risk of developing psychosis occurred } \\
\text { in patients who had started before the age of } 14 \text { ( } 2.5 \\
\text { times more risk) than those who had not started using } \\
\text { cannabis at that age. In addition, cannabis increases } \\
\text { the risk of psychosis regardless of COMT genotypes. }\end{array}$ \\
\hline
\end{tabular}


it is not possible to make direct comparisons between the samples in each study, although it is possible to arrive at some conclusions when making these comparisons. Results are given and discussed in the following subsections.

\section{Cannabis use and psychotic disorders}

There are several longitudinal studies in general population, together with systematic reviews and meta-analyses of cannabis use and psychotic disorders (Andréasson, Allebeck, Engström, \& Rydberg, 1987; Degenhardt \& Hall, 2006; Gage, Hickman, \& Zammit, 2016; Myles, Myles, \& Large, 2016; Moore et al., 2007; Roncero, Collazos, Valero, \& Casas, 2007), noting that cannabis use can increase the risk of developing lifetime psychotic disorders and schizophrenia two or threefold (Moore et al., 2007; Hall, 2006).

Specifically, in this correlation, we found 11 longitudinal studies evaluating cannabis use in adolescence together with the presence of psychosis, although only three clearly distinguished between early vs. late onset (Table 1). Since the definition of early onset varied between the studies, Arseneault et al. (2002) defined early onset as use before the age of 15, whereas for Zammit, Owen, Evans, Heron, and Lewis (2011) early onset of cannabis use was defined as beginning at 14. Caspi et al. (2005) described it as beginning before 18 . In any case, the risk of psychosis was greater for users who started at an early age (Arseneault et al., 2002; Caspi et al., 2005; Zammit et al., 2011). Thus the lifetime risk of presenting a psychotic disorder increased between 2.5 (Zammit et al., 2011) and four (Arseneault et al., 2002) times compared to those with later onset. The other studies relating cannabis use in adolescence to lifetime presence of psychosis also supported this correlation (Andréasson et al., 1987; Ferdinand et al., 2005; Fergusson, Horwood, \& Swain- Campbell, 2003; Fergusson, Boden, \& Horwood, 2006; Henquet et al., 2005; Kuepper et al., 2011; Manrique-García et al., 2012; Zammit et al., 2002). These findings have also been observed in retrospective studies (Veen et al., 2004).

On the other hand, some authors point out that starting at an early age not only increases the risk of presenting psychosis, but also makes it emerge at younger ages compared to later users or those who never use cannabis (Hall \& Degenhardt, 2007; Helle et al., 2016; Konings, Henquet, Maharajh, Hutchinson, \& van Os, 2008; Ksir \& Hart, 2016; Veen et al., 2004). In a recent meta-analysis, it points out that regular cannabis use precedes the onset of psychosis by 6.3 years (Myles et al., 2016). Consequently, and predicting that early onset of cannabis use would lead to greater cumulative lifetime exposure to cannabis, some authors have found that the risk clearly increases when the number of lifetime uses of cannabis exceeds 50 (van Os et al., 2002; Zammit et al., 2002). This is consistent with data indicating that dependence would increase the risk of presenting psy- chotic symptoms (Fergusson et al., 2003). Thus, early onset of cannabis use is a risk due to increased exposure, but also because of the characteristics of the adolescent brain that make it more vulnerable to the effects of cannabis, producing symptoms similar to psychotic ones and possibly psychotic spectrum disorders (Parolaro, 2010). It should also be noted that the age of onset is not the only risk factor, and that, for example, some authors point out that the use of cannabis in high doses is more important (Henquet et al., 2005).

Accordingly, cannabis is possibly not a necessary or sufficient cause, but acts amplifying the genetic vulnerability of the individual with other environmental risk factors, in the development of psychotic disorders (Degenhardt, Hall, \& Lynskey, 2003; Ksir \& Hart, 2016; van Winkel \& Genetic Risk and Outcome of Psychosis Investigators, 2011), or advance the appearance of positive psychotic symptoms by up to three years in these individuals (Helle et al., 2016). A systematic review posits the hypothesis that exposure to cannabis, especially during adolescence, could lead to immunological dysfunctions that could potentially cause latent vulnerability for psychosis and, in turn, increase the risk of schizophrenia (Suárez-Pinilla, López-Gil, \& Crespo-Facorro, 2014). It has been postulated that individuals genetically predisposed to suffering from schizophrenia are more likely to use cannabis and to do so in larger amounts. This does not mean that there is no causal relationship between cannabis use and the risk of schizophrenia, but it does establish that at least part of the association may be due to the causal relationship in the opposite direction (Power et al., 2014).

It has therefore been suggested that there is a population genetically vulnerable to developing psychotic symptoms in relation to the use of cannabis (Caspi et al., 2005; De Lisi, 2008), and therefore at a higher risk of developing psychotic disorders. However, not all studies support this theory (Zammit et al., 2011). Cannabis is known to influence various systems of neurotransmitters (Colizzi, McGuire, Pertwee, \& Bhattachryya, 2016; Sherif, Radhakrishnan, D'Souza, \& Radhakrishnan, 2016), which, through various interactions with the glutamate, dopaminergic, gabaergic, and endocannabinoid system could explain the risk of developing psychotic symptoms (Colizzi et al., 2016; Sherif et al., 2016). Several polymorphisms could be associated, including the Val (158) Met polymorphism in the catechol-O-methyltransferase (COMT) gene, which appears to modulate the association between cannabis use in adolescence and the age of onset of psychotic disorders (Estrada et al., 2011), increasing the risk of developing psychotic disorders in the event of early onset (beginning before age 18) (Caspi et al., 2005). However, not all studies support a relationship between COMT polymorphisms and the risk of psychotic disorders in people who begin using cannabis before the age of 14 (Zammit et al., 2011). One should therefore not overlook the fact that the effects may 
be partly conditioned by other factors of vulnerability to suffering from psychotic disorders (Henquet et al., 2005).

Lastly, there are other factors that could be associated with cannabis use at early ages and psychosis, such as childhood trauma, and specifically, non-consensual sexual experiences. It has been said that people who have suffered sexual abuse have a six times greater risk of having a psychotic episode than those who have not and if, in addition, the subject uses cannabis, s/he has, in addition, a seven times greater risk of developing a psychotic disorder (Houston, Murphy, Shevlin, \& Adamson, 2011; Sideli et al., 2015). However, some longitudinal studies indicate that the relationship between cannabis use and the subsequent presence of psychotic symptoms is unrelated to childhood trauma (Kuepper et al., 2011).

For all these reasons, and even if no definitive conclusions can be drawn about whether cannabis use is directly related to psychosis in adulthood, it seems sensible to inform vulnerable people that cannabis can cause acute psychotic symptoms, especially at high doses.

\section{Cannabis use, mood, and anxiety disorders}

Cannabis use is commonly associated with clinical depression, anxiety, and suicide (Alpert, Maddocks, Rosenbaum, \& Fava, 1994; Tournier, Sorbara, Gindre, Swendsen, \& Verdoux, 2003). Specifically, in this area, we found seven longitudinal studies exploring the relationship between cannabis use and mood disorders and/or anxiety. However only three papers specifically studied the presence of an early onset of cannabis use and the development of mood and anxiety disorders (Arseneault et al., 2002; Fergusson, Horwood, \& Swain-Campbell, 2002; Hayatbakhsh et al., 2007), although it must be said that the study by Arseneault et al. (2002) was primarily designed to study psychosis and that the non-correlation between early onset of cannabis and depression observed was a secondary finding. The age set as early onset of cannabis use in the three studies was similar (15 years) (Arseneault et al., 2002; Fergusson et al., 2002; Hayatbakhsh et al., 2007).

Hayatbakhsh et al. (2007) report that patients who began cannabis use before age 15 experienced anxiety and depression more frequently in early adulthood, and that this association is unrelated to personal or family history (Hayatbakhsh et al., 2007). However, this finding was not obtained in two similar studies, which state that the onset of cannabis use before the age of 15 did not predict lifetime depression (Arseneault et al., 2002; Fergusson et al., 2002), although it could predict the presence of suicidal behaviors (Fergusson et al., 2002).

As a result of the above and in comparison with other studies, the results of the various studies differ regarding the most frequent type of relationship between the two pathologies. Longitudinal studies conducted on adults tend to indicate that cannabis use increases the risk of depression (Marmorstein \& Iacono, 2011), while cross-sectional studies suggest that a history of depression explains the dysphoria associated with cannabis use (Bovasso, 2001; Moore et al., 2007). Research indicates a slight association between consumption and depression with a probability ratio of 1.4 or more among the most frequent users (without specifying age of onset) (Fernández-Artamendi, Fernández-Hermida, Secades-Villa, \& García-Portilla, 2011). It has been pointed out that the relationship between cannabis use and the presence of depressive symptoms is more frequent in women (Patton et al., 2002; Poulin, Hand, Boudreau, \& Santor, 2005), and that the earlier and more frequent the use, the higher risk of depression (Hayatbakhsh et al., 2007). However, there is less evidence in this respect than on the association with psychotic disorders (Moore et al., 2007; Kendler, Prescott, Myers, \& Neale, 2003). Moreover, the psychosocial consequences of cannabis use partly explain the greater risk of developing a major depressive disorder (Marmorstein \& Iacono, 2011).

On the other hand, it should be considered that patients with primary depressive symptoms are at a higher risk of using cannabis (Feingold, Weiser, Rehm, \& Lev-Ran, 2015), and could use cannabis to improve their mood (Arendt et al., 2007; Kandel \& Chen, 2000; Kandel, Davies, Karus, \& Yamaguchi, 1986; Miller-Johnson, Lochman, Coie, Terry, \& Hyman, 1998). However, it has also been suggested that the direction of this relationship is inverse, in other words, cannabis use would increase the risk of depression and anxiety, with the decrease in motivation associated with use being a symptom of depression (Bovasso, 2001; Fergusson et al., 2002; Rey \& Tennant, 2002). Other authors have pointed out that there would be a common vulnerability conditioned by a genetic base and an unfavorable socio-environmental environment that would facilitate the emergence of the two pathologies in the same individual (Fu et al., 2002; Hall \& Degenhardt, 2007). Accordingly, adolescents would have a high prevalence of a history of traumatic parental divorce or abuse in childhood. In these cases, the clinical order would go from the traumatic experience to the presence of depressive symptomatology with a subsequent escalation to substance use (Hayatbakhsh et al., 2007; King, Iacono, \& McGue, 2004; Libby, Orton, Stover, \& Riggs, 2005).

No longitudinal studies were found specifically exploring the early use of cannabis and the lifetime development of bipolar disorder (BD). A longitudinal study found an association between cannabis use and the risk of presenting $\mathrm{BD}$, although this association disappeared after an adjustment of models (Feingold et al., 2015). Supporting the previous finding, several cross-sectional and retrospective studies relate the use of cannabis to BD (Feingold et al., 2015; van Laar, van Dorsselaer, Monshouwer, \& Graaf, 2007), and although there could be many factors involved in the BD-cannabis relationship (van Laar et al., 2007), it is 
suggested that early onset of cannabis use may be related to an earlier onset of BD (Lagerberg et al., 2011), and that its use is associated with a more severe development of BD (Lagerberg et al., 2016). Cannabis use is an important factor that can trigger an early onset of BD and, by itself, is associated with higher rates of suicidal behavior in BD. However, it is unclear whether or not the effect of cannabis at the age of onset of symptoms and suicide attempts are independent of each other (Leite et al., 2015). On the other hand, patients with $\mathrm{BD}$ engage in up to 6.8 times more cannabis use than controls (Agrawal, Nurnberger, Lynskey, \& The Bipolar Genome Study, 2011), with adolescents with BD being at a higher risk for the development of the disorder due to substance use (Wilens, 2004).

Lastly, we found a single longitudinal study relating early cannabis use (before the age of fifteen) with the presence of anxiety (Hayatbakhsh et al., 2007). This study is in line with longitudinal studies and meta-analyses that associate the use of cannabis (regardless of age at onset) with anxiety (Moore et al., 2007). However, this relationship between cannabis and anxiety is still controversial, and there are some studies where this association is not found (van Laar et al., 2007).

\section{DISCUSSION AND CONCLUSION}

The current review provides data on early cannabis use and the presence of mental disorders. Thus, use at an early age increases the risk of developing mental illnesses in adult life and/or means that they emerge earlier. This association is evident in the case of psychosis yet less clear in mood and anxiety disorders. In any case, due to the risk of developing these psychopathological disorders, it would be sensible to provide suitable psychoeducation and approaches in the presence of a patient with cannabis use disorder, especially if $\mathrm{s} /$ he is an adolescent. Cannabis is the most widely used illegal drug worldwide and has historically been regarded as innocuous (Fernandez, Tiffon, Solé, \& San, 2003). Its use is frequently banalized by adolescents, and even by their families, forming part of their lifestyle associated with the low perception of the risk involved in its use.

The association between cannabis use and the risk of presenting psychotic symptoms is very well known, although it has not been fully studied at the ages when use could pose the greatest risk. The current review suggests that cannabis use at an early age increases the lifetime risk of suffering psychotic disorders compared with those who begin using it later (Arseneault et al., 2002; Zammit et al., 2011). This risk could be partly be explained by the greater accumulated exposure (van Os et al., 2002; Zammit et al., 2002), genetic factors (Zammit et al., 2002), the increased vulnerability of the developing brain (Parolaro, 2010), alterations in neurotransmission (Colizzi et al., 2016; Sherif et al., 2016), and even immunological alterations (Suárez-Pinilla et al., 2014).

Regarding to mood disorders, there appears to be some association (especially in depression) if there has been an early onset of cannabis use, although current results tend to be contradictory. It is striking that some studies indicate that an early onset could be associated with later suicidal ideation (Fergusson et al., 2002), so the study on how early onset of cannabis use influences the subsequent presence of psychopathology should be prioritized in the field of dual disorders. There is a dearth of specific data on the relationship between anxiety and early onset of cannabis use. Although there would appear to be a relationship, more research is needed in this area to clarify the true relationship between early cannabis use and the future development of anxiety.

The current review has certain limitations, such as the fact that only articles in English and Spanish were reviewed, meaning that articles of great interest in other languages may have been omitted. At the same time, even though the studies were longitudinal, each study had a specific design with characteristics that may not be comparable with each other. Thus, for example, some studies were only performed on men (e.g., Andréasson et al., 1987). Moreover, there were a variety of follow-up times, ranging from 2 to 35 years. Even more importantly, the early onset of cannabis use criterion was arbitrary and there was no set definition.

Moreover, some studies were not specifically designed in keeping with the purpose of the current review, in other words, the findings of some studies were more incidental or associated findings. It is also important to emphasize that some studies failed to take into account the possibility of using other substances and/or polydrug use, which is important because the possibility that cannabis increases the risk of using other substances has been mentioned (Degenhardt et al., 2010; Fergusson, Boden, \& Horwood, 2006). It would therefore be useful to continue researching in this area, particularly to define various concepts such as early onset and not only to explore the correlations between early use and psychopathology, but also with associated factors (such as use of other drugs, genetic/family factors, psychosocial factors).

Although age of onset of use is a factor that influences the development of a psychosis, there is less evidence of the association between cannabis and anxiety disorder and mood. It is also important to note that there are other factors that may contribute to the development of mental disorders after an early onset of cannabis use, such as the amount of the substance used and the amount accumulated throughout one's lifetime. However, given the risk posed by the use of cannabis for adolescent health, this should not be neglected. Treatment schemes should use a multidisciplinary perspective, in order to inform adolescents, and detect its use and the associated consequences. It is possible to conclude that 
cannabis use is a global problem, and that cannabis use at an early age constitutes a risk factor in the development of certain mental disorders.

\section{Funding}

None.

\section{Conflicts of interest}

The authors declare they have no conflicts of interest.

\section{Acknowledgements}

The authors are grateful to the psychologists Laia Rodríguez-Cintas, Nina Vela, Alejandra Herrero and Drs. Begoña Gonzalvo for reading the initial manuscript.

\section{REFERENCES}

Agrawal, A., Nurnberger, J.I., Lynskey, M.T, \& The Bipolar Genome Study. (2011). Cannabis involvement in individuals with bipolar disorder. Psychiatry Research, 185(3), 459-461. doi: 10.1016/j.psychres.2010.07.007

Alpert, J., Maddocks, A., Rosenbaum, J., \& Fava, M. (1994). Childhood psychopathology retrospectively assessed among adults with early onset major depression. Journal Of Affective Disorders, 31(3), 165-171.

Andréasson, S., Allebeck, P., Engström, A., \& Rydberg, U. (1987). Cannabis and schizophrenia a Longitudinal Study of Swedish Conscripts. The Lancet, 330(8574), 1483-1486.

Arendt, M., Rosenberg, R., Fjordback, L., Brandholdt, J., Foldager, L., Sher, L., \& Munk-Jørgensen, P. (2007). Testing the self-medication hypothesis of depression and aggression in cannabis-dependent subjects. Psychological Medicine, 37(7), 935-945.

Arseneault, L., Cannon, M., Poulton, R., Murray, R., Caspi, A., \& Moffitt, T.E. (2002). Cannabis use in adolescence and risk for adult psychosis: longitudinal prospective study. British Medical Journal, 325(7374), 1212-1213.

Bel, M.N., Inglés, M., \& Piñol, J.L. (2009). Estudios de Cohorte. Fisioterapia, 31(5), 218-223. doi:10.1016/j.ft.2009.03.001

Bovasso, G. (2001). Cannabis Abuse as a Risk Factor for Depressive Symptoms. American Journal of Psychiatry, 158(12), 2033-2037.

Caspi, A., Moffitt, T., Cannon, M., McClay, J., Murray, R., Harrington, H., ... \& Craig, I.W. (2005). Moderation of the Effect of Adolescent-Onset Cannabis Use on Adult Psychosis by a Functional Polymorphism in the Catechol-O-Methyltransferase Gene: Longitudinal Evidence of a Gene X Environment Interaction. Biological Psychiatry, 57(10), 1117-1127.

Colizzi, M., McGuire, P., Pertwee, R., \& Bhattacharyya, S. (2016). Effect of cannabis on glutamate signalling in the brain: A systematic review of human and animal evidence. Neuroscience \& Biobehavioral Reviews, 64, 359-381. doi: 10.1016/j. neubiorev.2016.03.010

Comisión Interamericana para el Control del Abuso de Drogas. (2006). Jóvenes y drogas en paises sudamericanos: un desafio para las politicas públicas: primer estudio comparativo sobre uso de drogas en población escolar secundaria de Argentina, Bolivia, Brasil, Colombia, Chile, Ecuador, Paraguay, Perú y Uruguay. Lima: Tetis Graf E.I.R.L. Retrieved from: http://cicad.oas.org/oid/NEW/ statistics/siduc/Estudio_Comparativo_resumenex.pdf

Curran, H., Freeman, T., Mokrysz, C., Lewis, D., Morgan, C., \& Parsons, L. (2016). Keep off the grass? Cannabis, cognition and addiction. Nature Reviews Neuroscience, 17(5), 293-306. doi: 10.1038/nrn.2016.28

Currie, C., Zanotti, C., Morgan, A., Currie, D., de Looze, M., Roberts, C., ... \& Barnekow, V. (2012). Social determinants of health and well-being among young people. Health Behaviour in School-aged Children (HBSC) study: International report from the 2009/2010 survey. Copenhague: WHO Regional Office for Europe (Health Policy for Children and Adolescents, No. 6). Retrieved from: http://www.euro.who.int/en/health-topics/Life-stages/ child-and-adolescent-health/publications/2012/social-determinants-of-health- and-well-being-among-young-people.-health-behaviour-in-school-aged-children-hbsc-study

Degenhardt, L., Coffey, C., Carlin, J., Swift, W., Moore, E., \& Patton, G. (2010). Outcomes of occasional cannabis use in adolescence: 10-year follow-up study in Victoria, Australia. The British Journal of Psychiatry, 196(4), 290-295. doi: 10.1192/bjp.bp.108.056952.

Degenhardt, L. \& Hall, W. (2006). Is Cannabis Use a Contributory Cause of Psychosis? The Canadian Journal of Psychiatry, 51(9), 556-565.

Degenhardt, L., Hall, W., \& Lynskey, M. (2003). Testing hypotheses about the relationship between cannabis use and psychosis. Drug and Alcohol Dependence, 71(1), 37-48.

Degenhardt, L., Ferrari, A., Calabria, B., Hall, W., Norman, R., McGrath, J., ... \& Vos, T. (2013). The Global Epidemiology and Contribution of Cannabis Use and Dependence to the Global Burden of Disease: Results from the GBD 2010 Study. Plos ONE, 8(10), e76635. doi: 10.1371/journal.pone.0076635

De Lisi, L. (2008). The effect of cannabis on the brain: can it cause brain anomalies that lead to increased risk for schizophrenia? Current Opinion in Psychiatry, 2l(2),140-150. doi: 10.1097/YCO.0b013e3282f51266

Estrada, G., Fatjó-Vilas, M., Muñoz, M., Pulido, G., Miñano, M., Toledo, E., ... \& Fañanás, L. (2011). Cannabis use and age at onset of psychosis: further evidence of interaction with COMT Val158Met polymorphism. Acta Psychiatrica Scandinavica, 123(6), 485-492. doi: 10.1111/j.1600-0447.2010.01665.x

European Monitoring Centre for Drugs and Drug Addiction. (2010). Annual Report 2011. The State of the drug problems in Europe. Luxembourg: Publications Office of the European Union. Retrieved From: http://www.emcdda.europa.eu/ publications/annual-report/2012

Ferdinand, R.F., Sondeijker, F., van der Ende, J., Selten, J.P., Huizink, A., \& Verhulst, F.C. (2005). Cannabis use predicts future psychotic symptoms, and vice versa. Addiction, 100(5), 612-618.

Feingold, D., Weiser, M., Rehm, J., \& Lev-Ran, S. (2015). The association between cannabis use and mood disorders: A longitudinal study. Journal of Affective Disorders, 172, 211-218. doi: 10.1016/j.jad.2014.10.006

Fergusson, D. M., Boden, J. M., \& Horwood, L. J. (2006). Cannabis use and other illicit drug use: testing the cannabis gateway hypothesis. Addiction, 101(4), 556-569.

Fergusson, D., Horwood, L., \& Swain-Campbell, N. (2002). Cannabis use and psychosocial adjustment in adolescence and young adulthood. Addiction, 97(9), 1123-1135.

Fergusson, D., Horwood, L., \& Swain-Campbell, N. (2003). Cannabis dependence and psychotic symptoms in young people. Psychological Medicine, 33(1), 15-21.

Fernández-Artamendi, S., Fernández-Hermida, J. R., Secades-Villa, R., \& García-Portilla, P. (2011). Cannabis y Salud Mental. Actas Españolas de Psiquiatría, 39(3), 180-90.

Fernandez, P., Tiffon, L., Solé, J., \& San, L. (2003). Cannabis dependence: clinical implications. Based and one case. Actas Españolas de Psiquiatría, 31(5), 299-301.

Fontes, M., Bolla, K., Cunha, P., Almeida, P., Jungerman, F., Laranjeira, R., ... \& Lacerda, A. L. (2011). Cannabis use before age 15 and subsequent executive functioning. The British Journal of Psychiatry, 198(6), 442-447. doi: 10.1192/ bjp.bp. 110.077479

Fu, Q., Heath, A. C., Bucholz, K. K., Nelson, E., Goldberg, J., Lyons, M. J., ... \& Eisen, S. A. (2002). Shared Genetic Risk of Major Depression, Alcohol Dependence, and Marijuana Dependence. Archives of General Psychiatry, 59(12), $1125-1132$.

Gage, S., Hickman, M., \& Zammit, S. (2016). Association Between Cannabis and Psychosis: Epidemiologic Evidence. Biological Psychiatry, 79(7), 549-556. doi: 10.1016/j.biopsych.2015.08.001

Gonzalvo, B., Barral, C., Grau-López, L., Esteve, O., \& Roncero, C. (2011). Psychiatric comorbidity in cannabis users. Trastornos Adictivos, 13(3), 109-112.

Hall, W. (2006). Is cannabis use psychotogenic? The Lancet, 367(9506), 193-195.

Hall, W., \& Degenhardt, L. (2007). Prevalence and correlates of cannabis use in developed and developing countries. Current Opinion in Psychiatry, 20(4), 393397.

Hayatbakhsh, M. R., Najman, J. M, Jamrozik, K., Mamun, A. A., Alati, R., \& Bor, W. (2007). Cannabis and Anxiety and Depression in Young Adults. Journal of The American Academy of Child \& Adolescent Psychiatry, 46(3), 408-417. 
Helle, S., Ringen, P., Melle, I., Larsen, T., Gjestad, R., Johnsen, ... \& Løberg, E. M. (2016). Cannabis use is associated with 3 years earlier onset of schizophrenia spectrum disorder in a naturalistic, multi-site sample $(\mathrm{N}=1119)$. Schizophrenia Research, 170(1), 217-221. doi: 10.1016/j.schres.2015.11.027

Henquet, C., Krabbendam, L., Spauwen, J., Kaplan, C., Lieb, R., Wittchen, H.U., \& van Os, J. (2005). Prospective cohort study of cannabis use, predisposition for psychosis, and psychotic symptoms in young people. British Medical Journal, 330(7481), 11-14. doi: 10.1136/bmj.38267.664086.63

Houston, J., Murphy, J., Shevlin, M., \& Adamson, G. (2011). Cannabis use and psychosis: re-visiting the role of childhood trauma. Psychological Medicine, 4l(11), 2339-2348. doi: 10.1017/S0033291711000559.

Kandel, D., \& Chen, K. (2000). Types of marijuana users by longitudinal course. Journal of Studies on Alcohol, 61(3), 367-378.

Kandel, D. B., Davies, M., Karus, D., \& Yamaguchi, K. (1986). The Consequences in Young Adulthood of Adolescent Drug Involvement. Archives of General Psychiatry, 43(8), 746-754.

Kendler, K. S., Prescott, C. A., Myers, J., \& Neale, M. C. (2003). The Structure of Genetic and Environmental Risk Factors for Common Psychiatric and Substance Use Disorders in Men and Women. Archives of General Psychiatry, 60(9), 929-937.

King, S. M., Iacono, W. G., \& McGue, M. (2004). Childhood externalizing and internalizing psychopathology in the prediction of early substance use. Addiction, 99(12), 1548-1559.

Konings, M., Henquet, C., Maharajh, H., Hutchinson, G., \& Van Os, J. (2008). Early exposure to cannabis and risk for psychosis in young adolescents in Trinidad. Acta Psychiatrica Scandinavica, 118(3), 209-213. doi: 10.1111/j.16000447.2008.01202.x

Kuepper, R., van Os, J., Lieb, R., Wittchen, H. U., Höfler, M., \& Henquet, C. (2011). Continued cannabis use and risk of incidence and persistence of psychotic symptoms: 10 year follow-up cohort study. British Medical Journal, 342(1), d738. doi: 10.1136/bmj.d738

Ksir, C. \& Hart, C. (2016). Cannabis and Psychosis: A Critical Overview of the Relationship. Current Psychiatry Reports, 18(2), 1-11. doi: 10.1007/s11920-0150657-y

Lagerberg, T. V., Icick, R., Andreassen, O. A., Ringen, P. A., Etain, B., Aas, M., ... \& Bellivier, F. (2016). Cannabis use disorder is associated with greater illness severity in tobacco smoking patients with bipolar disorder. Journal of Affective Disorders, 190, 286-293. doi: 10.1016/j.jad.2015.10.023

Lagerberg, T. V., Sundet, K., Aminoff, S. R., Berg, A.O., Ringen, P. A., Andreassen, O. A., \& Melle, I. (2011). Excessive cannabis use is associated with earlier age at onset in bipolar disorder. European Archives of Psychiatry and Clinical Neuroscience, 261(6), 397-405. doi: 10.1007/s00406-011-0188-4

Leite, R. T., Nogueira, S., do Nascimento, J. P., Lima, L. S., Nóbrega, T. B., Virgínio, M., ... \& de Matos, F. G. (2015). The Use of Cannabis as a Predictor of Early Onset of Bipolar Disorder and Suicide Attempts. Neural Plasticity, 2015, 1-13. doi: $10.1155 / 2015 / 434127$

Libby, A. M., Orton, H. D., Stover, S. K, \& Riggs, P. D. (2005). What came first, major depression or substance use disorder? Clinical characteristics and substance use comparing teens in a treatment cohort. Addictive Behaviors, 30(9), 1649-1662.

Manrique-Garcia, E., Zammit, S., Dalman, C., Hemmingsson, T., Andreasson, S., \& Allebeck, P. (2012). Cannabis, schizophrenia and other non-affective psychoses: 35 years of follow-up of a population-based cohort. Psychological Medicine, 42(6), 1321-1328. doi: 10.1017/S0033291711002078

Marmorstein, N. R, \& Iacono, W. G. (2011). Explaining associations between cannabis use disorders in adolescence and later major depression: A test of the psychosocial failure model. Addictive Behaviors, 36(7), 773-776.

Miller-Johnson, S., Lochman, J. E., Coie, J. D., Terry, R., \& Hyman, C. (1998). Comorbidity of conduct and depressive problems at sixth grade: substance use outcomes across adolescence. Journal of Abnormal Child Psychology, 26(3), 221-232.

Moore, T., Zammit, S., Lingford-Hughes, A., Barnes, T., Jones, P., Burke, M., \& Lewis, G. (2007). Cannabis use and risk of psychotic or affective mental health outcomes: a systematic review. The Lancet, 370(9584), 319-328.
Myles, H., Myles, N., \& Large, M. (2016). Cannabis use in first episode psychosis: Meta-analysis of prevalence, and the time course of initiation and continued use. Australian \& New Zealand Journal of Psychiatry, 50(3), 208-219. doi: 10.1017/ S0033291707009956

Parolaro, D. (2010). Adolescent cannabis consumption and schizophrenia: Epidemiological and experimental evidences. Adicciones, 22(3), 185-189.

Patton, G. C., Coffey, C., Carlin, J. B., Degenhardt, L., Lynskey, M., \& Hall, W. (2002). Cannabis use and mental health in young people: cohort study. British Medical Journal, 325(7374), 1195-1198.

Poulin, C., Hand, D., Boudreau, B., \& Santor, D. (2005). Gender differences in the association between substance use and elevated depressive symptoms in a general adolescent population. Addiction, 100(4), 525-535.

Power, R., Verweij, K., Zuhair, M., Montgomery, G., Henders, A., Heath, A., ... \& Martin, N. G. (2014). Genetic predisposition to schizophrenia associated with increased use of cannabis. Molecular Psychiatry, 19(11), 1201-1204. doi: $10.1038 / \mathrm{mp} .2014 .51$

Rey, J., \& Tennant, C. C. (2002). Cannabis and mental health. British Medical Journal, 325(7374), 1183-1184.

Roncero, C., Collazos, F., Valero, S., \& Casas, M. (2007). Cannabis consumption and development of psychosis: state of the art. Actas Españolas de Psiquiatría, 35(3), 182-189

Sherif, M., Radhakrishnan, R., D'Souza, D., \& Ranganathan, M. (2016). Human Laboratory Studies on Cannabinoids and Psychosis. Biological Psychiatry, 79(7), 526-538. doi: 10.1016/j.biopsych.2016.01.011

Sideli, L., Fisher, H., Murray, R., Sallis, H., Russo, M., Stilo, S., ... \& DiForti, M. (2015). Interaction between cannabis consumption and childhood abuse in psychotic disorders: Preliminary findings on the role of different patterns of cannabis use. Early Intervention in Psychiatry. doi: 10.1111/eip.12285

Suárez-Pinilla, P., López-Gil, J., \& Crespo-Facorro, B. (2014). Immune system: A possible nexus between cannabinoids and psychosis. Brain, Behavior and Immunity, 40, 269-282. doi: 10.1016/j.bbi.2014.01.018

Tournier, M., Sorbara, F., Gindre, C., Swendsen, J., \& Verdoux, H. (2003). Cannabis use and anxiety in daily life: A naturalistic investigation in a non-clinical population. Psychiatry Research, 118(1), 1-8.

United Nations Office on Drugs and Crime. (2008). World Drug Report 2015. Vienna: UNODC. Retrieved from: https:/www.unodc.org/documents/wdr2015/ World_Drug_Report_2015.pdf

van Laar, M., van Dorsselaer, S., Monshouwer, K., \& de Graaf, R. (2007). Does cannabis use predict the first incidence of mood and anxiety disorders in the adult population? Addiction, 102(8), 1251-1260.

van Os, J., Bak, M., Hanssen, M., Bijl, R. V., de Graaf, R., \& Verdoux, H. (2002). Cannabis Use and Psychosis: A Longitudinal Population-based Study. American Journal of Epidemiology, 156(4), 319-327.

van Winkel, R., \& Genetic Risk and Outcome of Psychosis Investigators. (2011). Family-based analysis of genetic variation underlying psychosis-inducing effects of cannabis: sibling analysis and proband follow-up. Archives of General Psychiatry, 68(2), 148-157. doi: 10.1001/archgenpsychiatry.2010.152

Veen, N., Selten, J., van der Tweel, I., Feller, W., Hoek, H., \& Kahn, R. (2004). Cannabis Use and Age at Onset of Schizophrenia. American Journal of Psychiatry, 161(3), 501-506.

Wilens, T. (2004). Attention-deficit/hyperactivity disorder and the substance use disorders: the nature of the relationship, subtypes at risk, and treatment issues. Psychiatric Clinics of North America, 27(2), 283-301.

Zammit S., Allebeck, P., Andreasson, S., Lundberg, I., \& Lewis, G. (2002). Self reported cannabis use as a risk factor for schizophrenia in Swedish conscripts of 1969: Historical cohort study. British Medical Journal, 325(7374), 1199-1201.

Zammit, S., Owen, M., Evans, J., Heron, J., \& Lewis, G. (2011). Cannabis, COMT and psychotic experiences. The British Journal of Psychiatry, 199(5), 380-385. doi: 10.1192/bjp.bp.111.091421 